\title{
Research Paper \\ Stressors and Coping Strategies During the Outbreak of Coronavirus Disease 2019 Among Hospital Staff: A Case Study in Iran
}

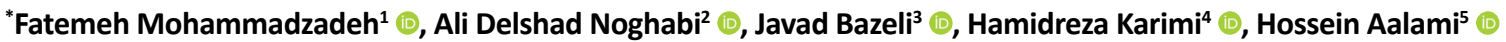 \\ 1. Department of Epidemiology \& Biostatistics, School of Health, Social Development \& Health Promotion Research Center, Gonabad University of Medical Sci- \\ ences, Gonabad, Iran. \\ 2. Social Development \& Health Promotion Research Center, Gonabad University of Medical Sciences, Gonabad, Iran. \\ 3. Department of Medical Emergencies, Social Development \& Health Promotion Research Center, School of Nursing, Gonabad University of Medical Sciences, \\ Gonabad, Iran. \\ 4. Department of Occupational Health, School of Health, Gonabad University of Medical Sciences, Gonabad, Iran. \\ 5. Department of Clinical Research Development Unit, Bohlool Hospital, Gonabad University of Medical Sciences, Gonabad, Iran.
}

$\begin{gathered}\text { Use your device to scan } \\ \text { and read the article online }\end{gathered}$
Outbreak of Coronavirus Disease 2019 Among Hospital Staff: A Case Study in Iran (Persian)]. Quarterly of "The Horizon of Medi-
cal Sciences". 2021; 27(2):148-163. https://doi.org/10.32598/hms.27.2.3289.1
dol https://doi.org/10.32598/hms.27.2.3289.1

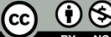

Received: 28 Jul 2020

Accepted: 11 Nov 2020

Available Online: 01 Apr 2021

Keywords:

Coping behaviors, CO-

VID-19, Health care

workers, Hospitals,

Mental health

\section{A B S TRACT}

Aims The emergence of COVID-19 disease has created significant stress and anxiety for health care workers. This study aimed to investigate the stressors and coping strategies in the staff of Allameh Bohlool Hospital in Gonabad City, Iran, during the outbreak of the COVID-19 disease.

Methods \& Materials This cross-sectional study was performed on 252 employees of Allameh Bohlool Hospital in Gonabad from March 2020 to April 2020. Study tools included a brief form of coping styles (Brief-COPE) and a researcher-made questionnaire of stressors due to the emergence of COVID-19 among health care workers. The obtained data were analyzed using linear regression and ordinal regression models at the significance level of 0.05 .

Findings About $74.2 \%, 69.4 \%, 52.7 \%, 52.7 \%$, and $99.2 \%$ of the hospital staff had moderate to high stress in the domains of internal, family-social, workplace-related, infection control, and government measures, respectively. The degree of using adaptive and maladaptive coping styles used by staff were $52.0 \%$ and $23.8 \%$ at the moderate to the high level, respectively. Maladaptive coping styles had a positive and significant relationship with stress intensity so that for each unit increase in maladaptive coping score, the odds of experiencing higher levels of stress increased 1.24 to 1.45 times $(P<0.001)$. Also, the odds of experiencing higher levels of stress in those who had sports activities was $24 \%$ to $76 \%$ lower $(P=0.003)$.

Conclusion The findings of the present study indicated a high level of stress among hospital staff. Also, the use of maladaptive coping styles and sports activities had a significant positive and negative relationship with stress intensity, respectively. Therefore, designing effective interventions focusing on reducing maladaptive coping patterns among hospital staff and encouraging people to engage in sports activities can help manage stress as much as possible due to the outbreak of COVID-19 disease.

\section{* Corresponding Author:}

Fatemeh Mohammadzadeh, PhD.

Address: Department of Epidemiology \& Biostatistics, School of Health, Social Development \& Health Promotion Research Center, Gonabad University of Medical Sciences, Gonabad, Iran.

Tel: +98 (51) 57223028

E-mail: fmhz.uni@gmail.com 


\section{English Version}

\section{Introduction}

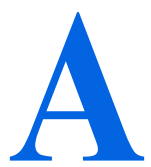

$t$ the end of 2019, several cases of unknown and fetal pneumonia were reported in China's Hubei Province due to a new virus called coronavirus acute respiratory syndrome 2 (SARS-Cov2).

This infectious disease, known as COVID-19, spread rapidly worldwide and was recognized as a pandemic by the World Health Organization (WHO) [1, 2]. As of June 19, 2020, the World Health Organization has reported more than 8366000 confirmed cases and more than 450000 deaths in 216 countries, regions, or territories due to COVID-19 [3]. The average incubation period for this disease is 5.2 days, and its common symptoms are fever, fatigue, dry cough, and shortness of breath. However, in some cases, it is asymptomatic [4]. Because of the higher rate of transmission, the mortality rate of COVID-19 is higher than the overall mortality rate of other diseases belonging to the Coronavirus family, such as Severe Acute Respiratory Syndrome (SARS) and the Middle East Respiratory Syndrome (MERS) [5, 6].

In Iran, the first confirmed case of COVID-19 infection was reported on February 19, 2020, in Qom City [7] and is now one of the countries with the highest number of cases [3]. Lack of effective treatment or vaccination for COVID-19 has made it a major stressor, especially for Health Care Workers (HCWs) who are at high risk for catching COVID-19. During the outbreak of COVID-19, various factors caused concern and stress in HCWs. Part of this stress can be related to a person's characteristics and his or her assessment of changing circumstances. Another part is related to the family and the community, including fear of transmitting the disease to their family, lack of support from the family, and social stigma as a disease source. Another part is work-related issues such as increased workload due to the influx of suspicious and approved COVID-19 cases, high expectations in the workplace, constantly updated protocols, and lack of support from colleagues and the organization. Another part has to do with infection control, such as shortage of personal protective equipment, feeling the need for more education, and uncertainty about effective disease control. The last part has to do with what governments need to do to control and combat the virus, such as restricting travel, isolating patients in particular hospitals, and closing schools and shopping malls $[8,9]$. In addition to physical health, working in these stressful situations not only affects the focus, cognitive function, and decisionmaking ability of HCWs but can also have a long-term effect on their well-being and mental health [10]. Previous studies have shown an association between epidemics of infectious diseases, including SARS, MERS, and 2009 influenza A (H1N1), and mental health problems in HCWs [11-13]. High job stress, social isolation, fear, physical and mental fatigue, lifestyle changes, and absenteeism despite a high sense of responsibility are some of the cases that have been reported during the outbreak of past infectious diseases in health workers [14-16].

People use different coping strategies in the face of stressful situations. Effective coping strategies can reduce stressors and prevent short-term and long-term effects of stress [17]. Coping can be defined as cognitive and behavioral efforts to manage internal and external needs in stressful situations [18].

Coping strategies are divided into two basic types of adaptive and maladaptive coping. Adaptive coping is generally a problem-solving strategy aimed at changing, reducing, and eliminating stressors, while maladaptive coping typically refers to emotion-based strategies and manage stress by focusing on oneself and reducing unpleasant emotions and feelings [19]. Maladaptive coping is mainly used when people do not have the power to change and deal with a stressful situation [20].

The type and extent of stress and coping strategies during the outbreak of COVID-19 may vary among HCWs in different communities. Epidemiological data on mental health issues related to COVID-19 can help design effective interventions and plans to reduce the adverse effects of the disease, as well as to prepare for the spread of possible and similar infections in the future. However, few studies have been conducted on this topic in Iran. Therefore, this study was conducted for the first time to investigate stressors and identify the factors affecting stress based on demographic variables and coping strategies during the outbreak of COVID-19 disease as a case study in the staff of Allameh Bohlool Hospital in Gonabad City, Iran.

\section{Materials and Methods}

This cross-sectional study was performed on the staff of Allameh Bohlool Hospital in Gonabad City, Khorasan Razavi Province, during the first peak of the outbreak of COVID-19 disease in Iran, between March 2020 and April 2020. The minimum sample size required was 199 people with a $95 \%$ confidence interval, test power of 0.8 , and small effect size of 0.2 , which increased to 229 people because of a $15 \%$ potential dropout. The inclusion criteria included being employed in Allameh Bohlool Gonabadi Hospital, willingness to participate in the study, no recent hospitalization 
history for the participant or his family due to acute respiratory disease or COVID-19, and no recent death history in the participant's family due to acute respiratory disease or COVID-19. The convenience sampling method was used. To collect data, after preparing the online questionnaire, we sent its link to the hospital staff via SMS, WhatsApp, and Telegram, and they were asked to participate in the study if they wished.

The research questionnaire consisted of three parts. The first part was related to personal characteristics, including gender, age, marital status, work experience, education level, occupation, history of underlying diseases, and smoking. In the second part, a researcher-made questionnaire was used to assess the stressors of HCWs during the COVID-19 pandemic. The questionnaire consisted of 25 items in five domains of internal factors (5 items), family-social factors (6 items), workplace-related factors ( 7 items), infection control factors (4 items), and factors related to government actions ( 3 items). The items were scored on a 5-point Likert scale from $1=$ "very low" to 5 = "very high". The stress score in each domain was obtained from the sum of related questions, and the total score was obtained from the sum of scores in all domains, which was categorized into none, mild, moderate, and severe stress based on the scores' distribution quarters. The content validity of this test was confirmed based on the opinion of experts. Its reliability was evaluated using the Cronbach alpha, whose values ranged from 0.63 to 0.88 for test domains and 0.87 for the whole questionnaire. The third part was related to the review of coping strategies in employees, which was evaluated using a standard short form of coping strategies questionnaire (Brief-COPE). This questionnaire was designed by Carver [21] and consisted of 28 items in two subscales of adaptive and maladaptive strategies. Adaptive strategies include active coping, planned coping, use of emotional support, use of instrumental support, positive reframing, acceptance, religion, and humor. Maladaptive strategies include venting, denial, substance abuse, behavioral disengagement, and self-distraction and self-blame. Items are scored on a 4-point Likert scale (1="Never", 2="Sometimes", 3="Often", 4= "Always"). The score of each subscale is obtained from the sum of the scores of the related items. This questionnaire has been used in several studies in Iran, and its validity and reliability have been confirmed. In this study, the reliability of the questionnaire was evaluated using the Cronbach's alpha, whose values were 0.60 and 0.73 for adaptive and maladaptive styles, respectively.

Data analysis was performed using SPSS version 16. Descriptive statistics were presented for quantitative variables by mean and Standard Deviation (SD) and for qualitative variables by frequency and percentage. To investigate the relationship between individual characteristics and coping behaviors, we used a simple linear regression model, and variables that had a $\mathrm{P}<0.2$ were included in the multiple linear regression model. The assumptions of the linear regression model include the normality of the response variable for different values of the independent variable using the Kolmogorov-Smirnov goodness of fit test, the homogeneity of variance using the residual plot versus predicted values, and the independence of the residuals using the residual plot versus time sequence were also examined. An ordinal regression model was used to evaluate the effect of coping behaviors on stress levels by adjusting the effect of other variables. First, their significance in univariate analysis was investigated using a simple ordinal regression model, and if their $\mathrm{P}<0.2$, they were entered the multiple ordinal regression model, and the significance level was considered 0.05 .

\section{Results}

Data on 252 individuals were collected and analyzed. The characteristics of the participants are presented in Table 1. The Mean \pm SD age of the subjects was $34.7 \pm 3.0$ years. The minimum age was 22 , and the maximum was 52 years. The Mean \pm SD work experience was $8.6 \pm 7.7$ years, which varied between 1 and 26 years.

The Mean \pm SD score of stress in each of the domains of internal factors, family-social factors, factors related to the workplace, factors related to infection control, and factors related to government actions were $17.4 \pm 8.1,20.4 \pm 5.3$, $22.5 \pm 0.2,13.3 \pm 7.3$, and $13.5 \pm 5.6$, respectively.

Findings of the study showed that in 187 people (74.2\%) in the domain of personal factors, 175 people $(69.4 \%)$ in the domain of family-social factors, 133 people $(52.7 \%)$ in the domain of factors related to workplace and control infection and 247 people (99.2\%) in government measures had moderate to severe stress. The Mean \pm SD total score of stress was $91.2 \pm 2.2$, so that 156 people $(61.9 \%)$ had moderate stress levels and 43 people (17.1\%) had severe stress. Among the various stressors related to the outbreak of COVID-19 disease, the highest stressors were related to feeling high risk due to exposure to COVID-19 infection $(69.5 \%)$, fear of transmitting the disease to family members (78.2\%), increased workload due to the epidemic of COVID-19 disease (63.1\%), lack of security in infection control despite the use of standard precautions (61.1\%) and the need for government measures, including travel restrictions (94.0\%), isolating patients in special hospitals $(96.0 \%)$ and closing schools and shopping centers $(88.5 \%)$.

The study results showed that hospital staff uses both adaptive and maladaptive coping behaviors to deal with the 
Table 1. The characteristics of study participants

\begin{tabular}{|c|c|c|c|c|c|}
\hline & & & & ss Level No. & \\
\hline & & & Nhanglnail & Madongto & cavant \\
\hline & Female & $119(52.8)$ & 26 (49.1) & 62 (39.7) & $31(72.1)$ \\
\hline Genaer & Male & $113(47.2)$ & 27 (50.9) & $94(60.3)$ & $12(27.9)$ \\
\hline & Diploma and less & $45(17.8)$ & $9(17.0)$ & $23(14.7)$ & $13(30.2)$ \\
\hline Level of Education & Associate and bachelor & $154(61.1)$ & $29(54.7)$ & $100(64.1)$ & 25. $(58.2$ \\
\hline & Masters and higher & $53(21.1)$ & $15(28.3)$ & $33(21.2)$ & $5(11.6)$ \\
\hline & Married & $206(81.7)$ & $46(86.8)$ & $126(80.8)$ & $34(79.1)$ \\
\hline & Single/divorced/ widowed & $46(18.3)$ & $7(13.2)$ & $30(19.2)$ & $30(19.2)$ \\
\hline & Physician / nurse & $84(33.3)$ & $18(34.0)$ & $53(34.0)$ & $13(30.2)$ \\
\hline Occupation & Allied health professions & $122(48.4)$ & $25(47.2)$ & $70(44.9)$ & $27(62.8)$ \\
\hline & Administrative & $46(18.3)$ & $10(18.8)$ & $33(21.2)$ & $3(7.0)$ \\
\hline & No & $223(88.5)$ & $47(88.7)$ & $140(89.7)$ & $36(83.7)$ \\
\hline mistory of underiyng uisedse & Yes & $29(11.5)$ & $6(11.3)$ & $16(10.3)$ & $7(16.3)$ \\
\hline & No & $208(82.5)$ & 45 (84.9) & $127(81.4)$ & $36(83.7)$ \\
\hline 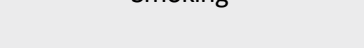 & Yes & $44(17.5)$ & $8(15.1)$ & $29(18.6)$ & $7(16.3)$ \\
\hline & No & $116(46.0)$ & $18(34.0)$ & $72(46.2)$ & $26(60.4)$ \\
\hline Doing sports activitues & Yes & $136(54.0)$ & $35(66.0)$ & $84(53.8)$ & $17(39.6)$ \\
\hline Working in the ward of pa- & No & $222(88.1)$ & $44(83.0)$ & $144(92.3)$ & $34(79.1)$ \\
\hline Cletils woicticuvide- & Yes & 30 (11.9) & $9(17.0)$ & $12(7.7)$ & $9(20.9)$ \\
\hline
\end{tabular}

stress caused by COVID-19 disease. The Mean \pm SD scores of adaptive and maladaptive coping styles were $40.10 \pm 6.8$ and $24.7 \pm 8.6$, respectively. In other words, the score of adaptive coping styles based on score distribution quarters was moderate for 93 people (36.9\%) and high for 38 people $(15.1 \%)$, and the score of maladaptive coping style was at a moderate level for 50 people $(19.8 \%)$ and a high level for 10 people $(4.0 \%)$.

The assumption of variable response normality in the linear regression model was confirmed based on the Kolmogorov-Smirnov test for residuals $(\mathrm{P}=0.279$ and $\mathrm{Z}=0.992$ ). The assumptions of homogeneity of variance and residual independence were also confirmed. The results of a multiple linear regression model showed that women were more likely than men to use both adaptive $(\mathrm{P}<0.001)$ and maladaptive coping styles $(\mathrm{P}=0.049)$. Also, people with higher education used less maladaptive methods $(\mathrm{P}<0.05)$. People who had sports activities also used more adaptive coping styles $(\mathrm{P}=0.046)$ (Table 2$)$.

In examining the relationship between adaptive and maladaptive coping styles and the amount of stress caused by COVID-19, the results of multiple ordinal regression showed that the maladaptive coping style had a positive and significant relationship with stress severity level. In other words, one unit increase in maladaptive coping styles, experiencing higher levels of stress increases 1.24 to 1.45 times $(\mathrm{P}<0.001)$. Also, people with no sports activities ex- 
Table 2. The relationship between individual characteristics and adaptive and maladaptive coping styles using the linear regression model

\begin{tabular}{|c|c|c|c|c|c|c|}
\hline \multirow{3}{*}{$\begin{array}{l}\text { Regression Model } \\
\text { Predictive Variables }\end{array}$} & \multicolumn{3}{|c|}{ Adaptive Coping } & \multicolumn{3}{|c|}{ Maladaptive Coping } \\
\hline & \multirow{2}{*}{$\begin{array}{l}\text { Simple } \\
\text { B (SE) }{ }^{\dagger}\end{array}$} & \multicolumn{2}{|c|}{ Multiple } & \multirow{2}{*}{$\begin{array}{c}\text { Simple } \\
\text { B (SE) }\end{array}$} & \multicolumn{2}{|c|}{ Multiple } \\
\hline & & B (SE) & $\mathbf{P}$ & & B (SE) & $\mathbf{P}$ \\
\hline Work experience & $0.04(0.05)$ & \multicolumn{2}{|c|}{---} & $-0.04(0.04)$ & \multicolumn{2}{|c|}{----- } \\
\hline Gender (female) a & $3.19(0.67)^{* *}$ & $3.14(0.67)$ & $<0.001$ & $0.73(0.48)^{\ddagger}$ & $0.94(0.78)$ & 0.049 \\
\hline
\end{tabular}

Level of education ${ }^{b}$

\begin{tabular}{|c|c|c|c|c|c|c|}
\hline Associate and Bachelor & $2.33(0.91)^{* *}$ & $2.33(0.87)$ & 0.136 & $-1.44(0.63)^{*}$ & $-1.42(0.63)$ & 0.024 \\
\hline Master and above & $3.96(1.09)^{\ddagger}$ & $3.76(1.04)$ & 0.166 & $-3.64(0.75)^{* *}$ & $-3.62(0.75)$ & $<0.001$ \\
\hline Marital status (married) ${ }^{c}$ & $0.88(0.89)$ & --- & --- & $-0.67(0.63)$ & --- & --- \\
\hline History of underlying disease (yes) ${ }^{d}$ & $-1.72(1.08)$ & $-0.98(1.02)$ & 0.728 & $0.65(0.77)$ & --- & --- \\
\hline Smoking (yes) ${ }^{d}$ & $-1.39(0.91)^{\ddagger}$ & $-0.36(0.87)$ & 0.556 & $0.83(0.64)^{\ddagger}$ & $0.89(0.63)$ & 0.154 \\
\hline Doing sports (yes) ${ }^{d}$ & $0.89(0.69)^{\ddagger}$ & $-1.23(0.65)$ & 0.046 & $-0.06(0.49)$ & --- & --- \\
\hline
\end{tabular}

${ }^{* *} \mathrm{P}<0.001,{ }^{*} \mathrm{P}<0.01,{ }^{\dagger} \mathrm{P}<0.05,{ }^{\dagger} \mathrm{P}<0.2,{ }^{a}$ Reference group: male, ${ }^{\mathrm{b}}$ Reference group: diploma and lower, ${ }^{\mathrm{c}}$ Reference group: single/

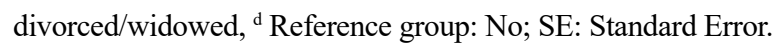

perience between 1.32 and 3.84 times higher stress levels than others $(\mathrm{P}=0.003)$ (Table 3$)$.

\section{Discussion}

The present study was a descriptive cross-sectional study that was performed to determine the stressors and coping strategies during the outbreak of COVID-19 disease in the staff of Allameh Bohlool Gonabadi Hospital.

Various studies show that the epidemic of infectious diseases, including SARS, MERS, and new influenza A of 2009 (A/H1N1) and COVID-19, has been accompanied by some psychological problems for HCWs. A similar study during the COVID-19 epidemic in Wuhan, China, found that $29.8 \%$ of HCWs suffered from stress [10]. Another study conducted during the SARS outbreak in Taiwan found that more than $70 \%$ of HCWs experienced anxiety, worry, and depression [22]. In a study in Greece, more than 50\% of HCWs reported relatively high levels of anxiety during the H1N1 influenza pandemic [16]. A study in Saudi Arabia also reported high levels of concern in $25 \%$ of HCWs due to the outbreak of MERS [9]. The present study results also showed that a significant proportion of hospital staff (79\%) suffer from stress caused by COVID-19 disease, so that $61.9 \%$ of staff experience moderate levels of stress and
$17.1 \%$ severe levels of stress. Among the various stressors related to the outbreak of COVID-19 disease, the highest stressors were related to feeling high risk due to exposure to COVID-19 infection, fear of transmitting the disease to family members, increased workload due to the COVID-19 epidemic, lack of security in infection control despite the use of standard precautions and the need for government measures included restricting travel, isolating patients in special hospitals, and closing schools and shopping malls.

This study showed that women were more likely than men to use adaptive and maladaptive coping strategies, consistent with the results of previous studies. In general, women tend to report higher scores of coping styles than men, regardless of their type [23, 24]. Also, people with higher education used less maladaptive coping styles. This finding was consistent with the findings of Leit et al. study [25]. People with higher education typically have higher levels of thinking and a wider range of coping strategies that can contribute to better coping and well-being behaviors $[26,27]$. People with sports activity also used more adaptive coping styles, which was similar to the results of Kim et al.'s study [28]. People who engage in sports activities are more likely to have positive thoughts and a calmer mind in the face of stressful situations. Instead of trying to 
Table 3. The relationship between adaptive and maladaptive coping styles with stress levels using an ordinal regression model

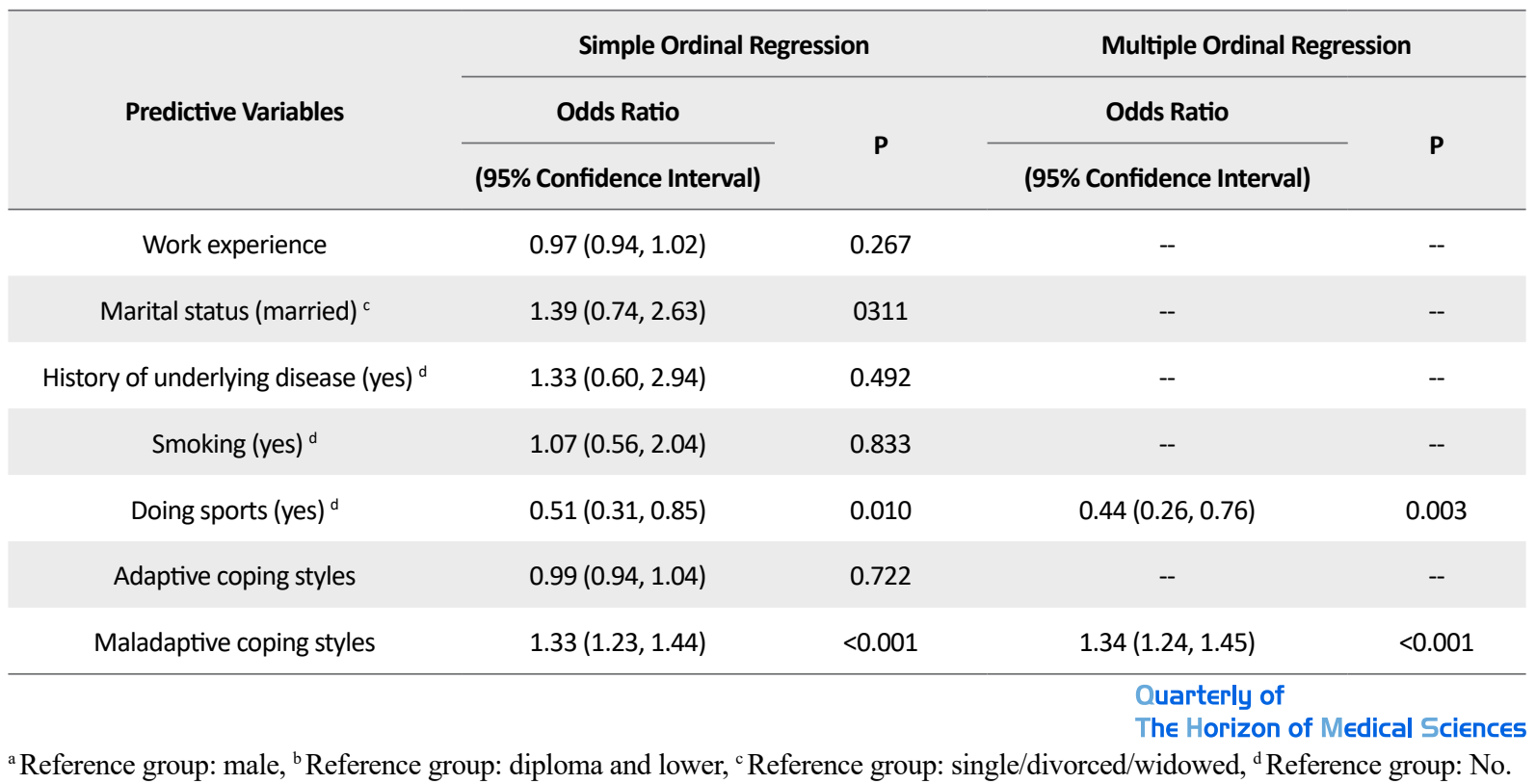

distract, blame, discharge, or ignore problems, they focus more on problem-solving [28, 29].

In the present study, the maladaptive coping style had a positive and significant relationship with stress severity level, so that for each unit increase in maladaptive coping score, the odds of experiencing higher levels of stress increased 1.23 to 1.45 times. Some other studies have shown that maladaptive coping is associated with negative consequences such as increased stress and anxiety [30, 31]. Also, in this study, people with sports activities exercise suffered less stress. The exact mechanism of the effect of exercise on stress reduction is not clear. Studies show that physical activity can affect mood and behavior by altering hormone levels, increasing neurotransmitters and levels of dopamine and serotonin in the body $[32,33]$.

This study has some limitations. First, this study's design was cross-sectional, and therefore statistical relationships do not necessarily indicate a cause-and-effect relationship. Second, due to the lack of a standard questionnaire on stressors during the outbreak of COVID-19, a researchermade questionnaire was used, which can be less precise than standard questionnaires. Third, filling out self-report questionnaires may be another source of bias in this study.

\section{Conclusion}

Overall, this study's findings indicate a significant level of stress among hospital staff during the outbreak of COVID-19. Employees used both adaptive and maladaptive coping styles to cope with the stress of COVID-19 disease.
People who used maladaptive coping styles experienced higher stress levels, while those who did sports activities experienced lower levels of stress. Therefore, designing effective interventions focusing on reducing maladaptive coping styles among employees and encouraging them to engage in sports activities can help manage the increased stress caused by the outbreak of COVID-19 disease.

\section{Ethical Considerations}

\section{Compliance with ethical guidelines}

This study was approved by the Ethics Committee of the Gonabad University of Medical Sciences (Code: IR . GMU.REC.1398.191). Also, This study was approved by the Clinical Research Development Unit of Allameh Bohlool Gonabadi Educational, Research, and Treatment Center, Gonabad University of Medical Sciences (Code: A-10-1520-1). At the beginning of the online questionnaire, the necessary information about the study and its objectives were provided to the participants, and they were asked to participate in the study if they were interested. Online questionnaires were also filled out anonymously.

\section{Funding}

This study was conducted with the financial support of the Clinical Research Development Unit of Allameh Bohlool Gonabadi Educational, Research, and Treatment Center, Gonabad University of Medical Sciences. 


\section{Authors' contributions}

Presenting the research concept, data analysis, and writing the draft: Fatemeh Mohammadzadeh; Study design: Fatemeh Mohammadzadeh, Ali Delshad Noghabi, Javad Bazli, and Hamidreza Karimi; Data collection: Ali Delshad Noghabi and Hossein Aalami; Preliminary review of the article and approval of the final version: Fatemeh Mohammadzadeh, Ali Delshad Noghabi, Javad Bazli, Hamidreza Karimi, and Hossein Aalami.

Conflicts of interest

The authors declared no conflict of interest.

\section{Acknowledgements}

The authors would like to thank the Vice-Chancellor for Research and Technology and the Clinical Research Development Unit of Allameh Bohlool Gonabadi Educational, Research, and Treatment Center, Gonabad University of Medical Sciences, the staff and officials of Allameh Bohlool Gonabadi Hospital. 


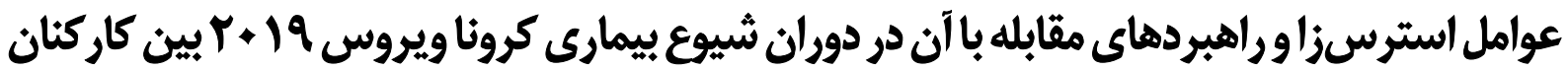 بيمارستان: يك مطالعه موردى در اير مقان
}

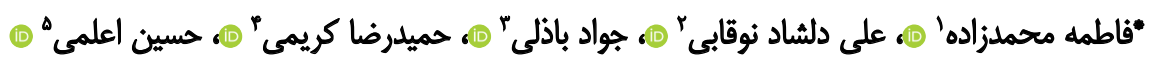

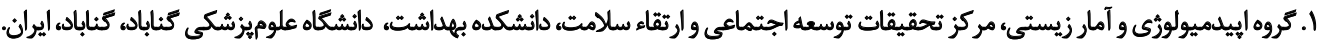

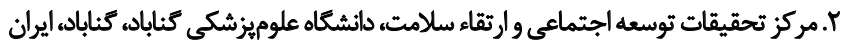

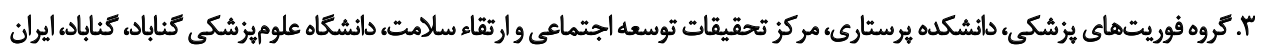

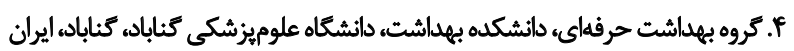

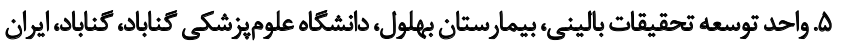

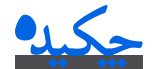

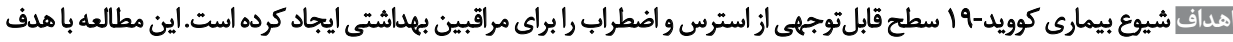

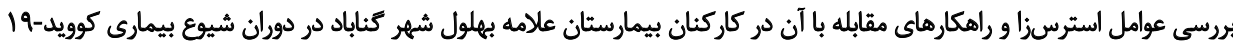
انجام شد.

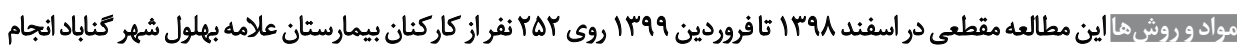

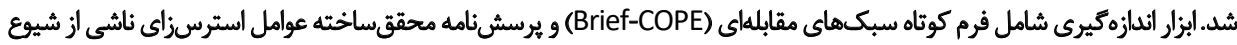

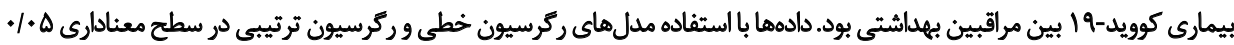
تجزيه وتحليل شد.

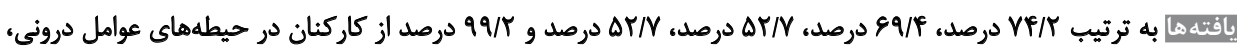

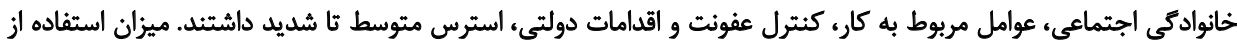

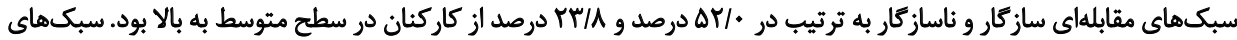

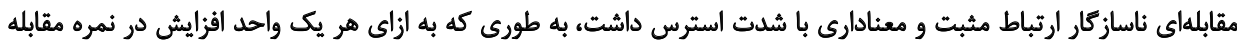

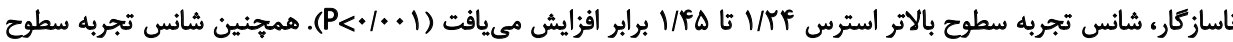

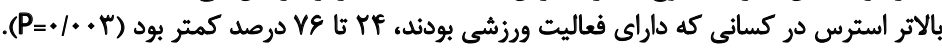

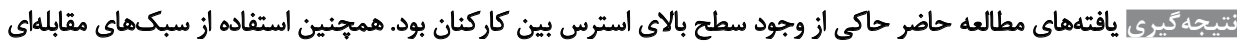

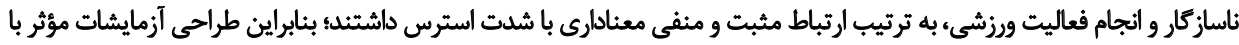

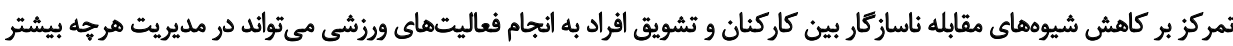

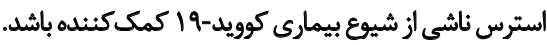

تاريخ دريافت: V• مرداد

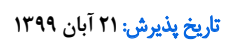

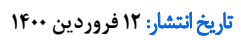

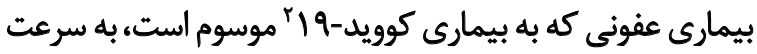

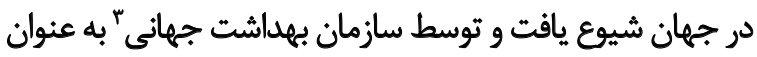

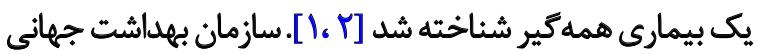

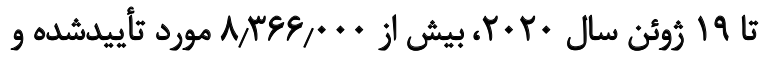

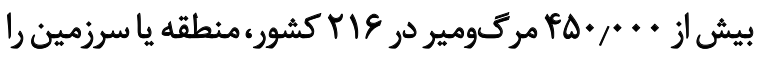

$$
\begin{aligned}
& \text { كليدوأوهها: } \\
& \text { راهبردهاى مقابله، } \\
& \text { كوويد-19، مراقبين } \\
& \text { بهداشتى، بيمارستانها، } \\
& \text { سلامت روان }
\end{aligned}
$$

در بايان سال 19+r، جندين مورد تهديدكنينده ينومونى

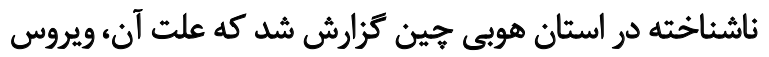

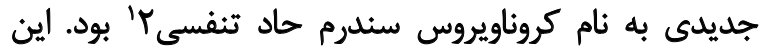

$$
\text { ㄷ. }
$$

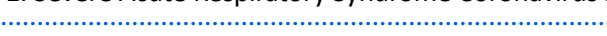

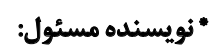

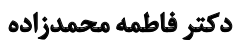

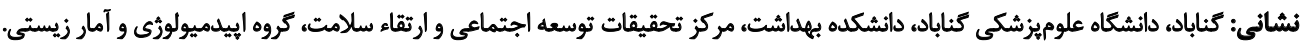

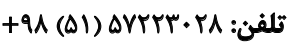

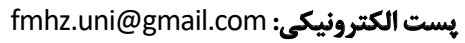


افراد در مواجهه با شرايط استرسزا از راهبردهاى مقابلهاى

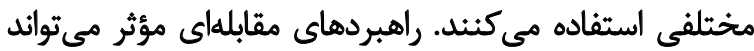

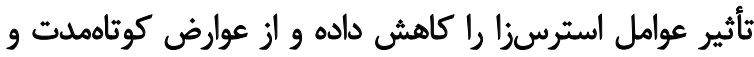

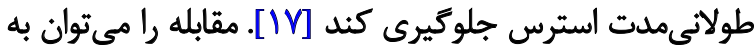

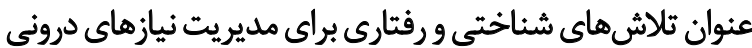

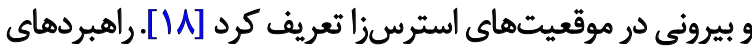

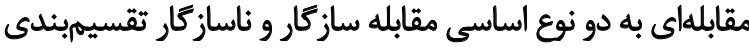

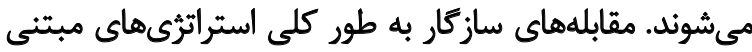

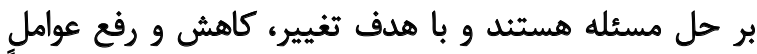

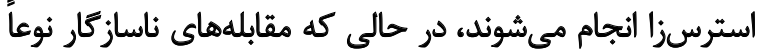

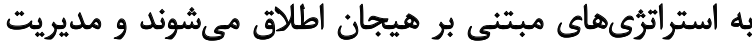

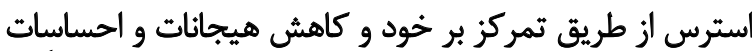

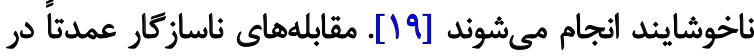

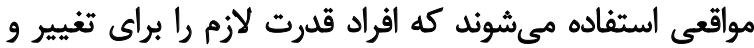

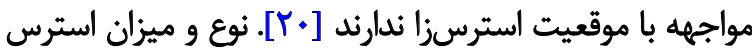

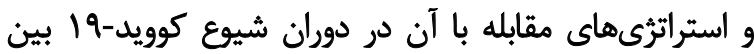

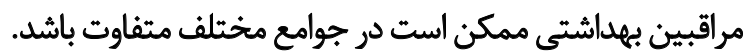

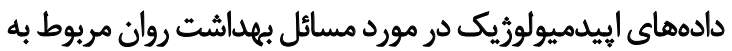

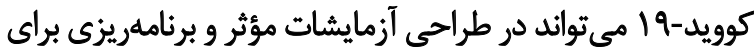

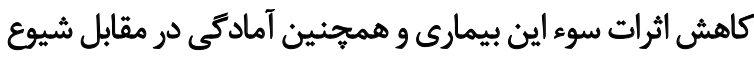

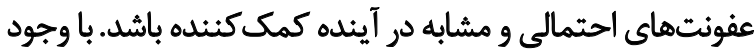

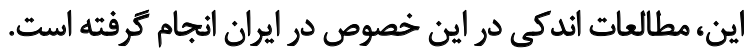

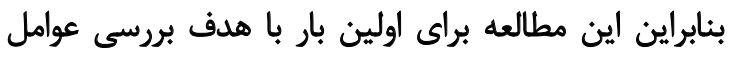

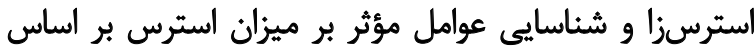

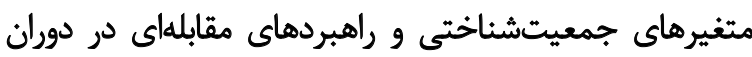

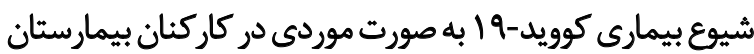
علامه بهلول شهر كناباد انجام شد.

\section{مواد وروشها}

اين مطالعه مقطعى در دوران موج اول شيوع بيمارى

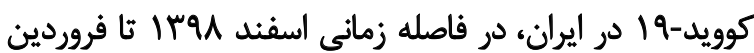

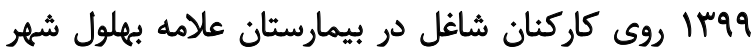

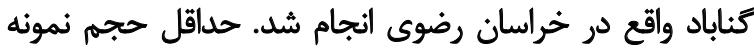

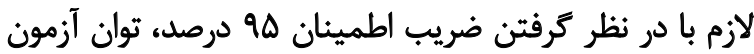

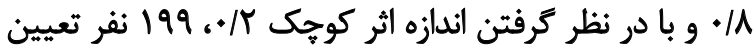

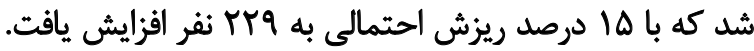

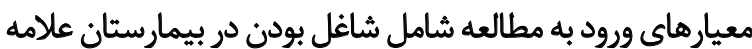

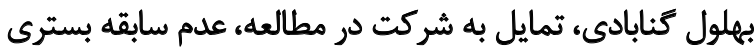

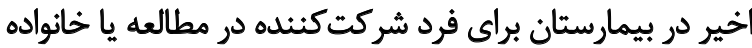

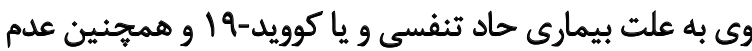

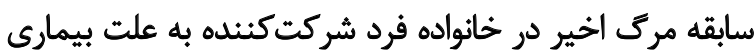

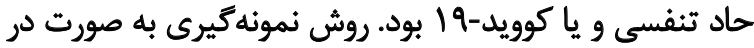

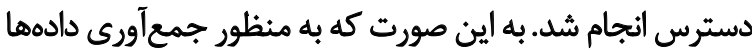

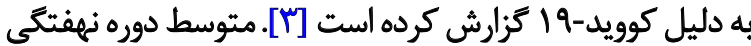

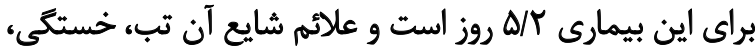

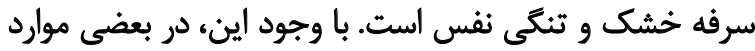

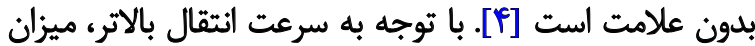

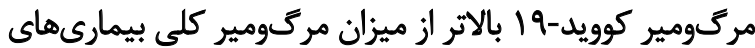

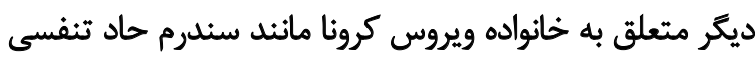

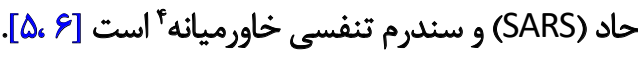
در ايران، اولين مورد تأييدشده از عفونت كوويد-19 در 19

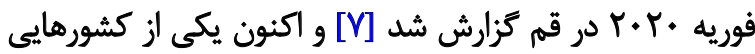

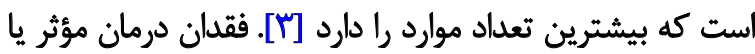

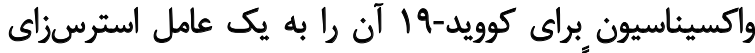

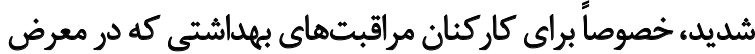

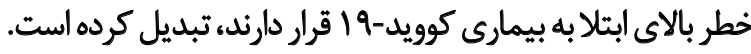

در طى شيوع كوويد-9 19، عوامل مختلفى مى تواند باعث ايجاد

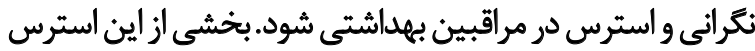

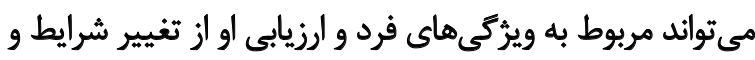

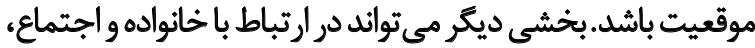

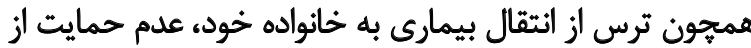

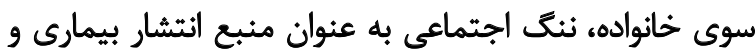

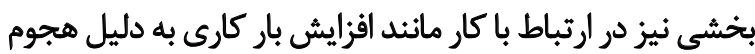

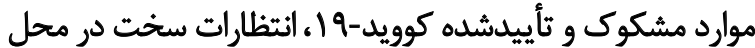

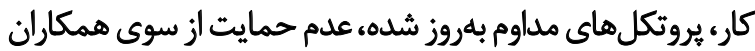

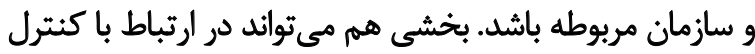

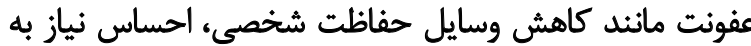

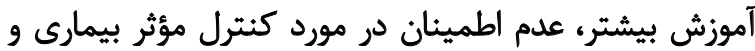

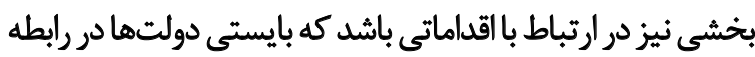

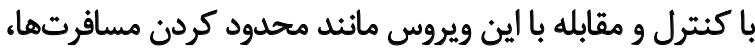

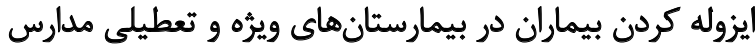

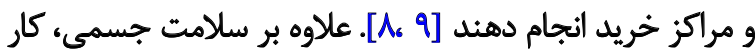

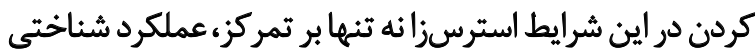

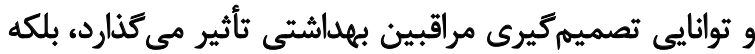

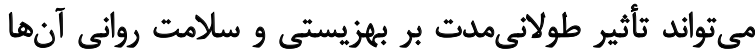

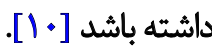

مطالعات قبلى شواهدى را در مورد ارتباط بين همه ئيرىهاى

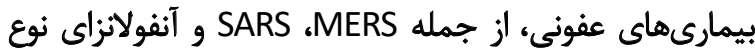

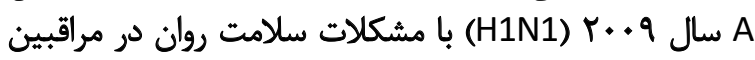

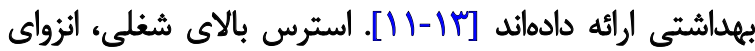

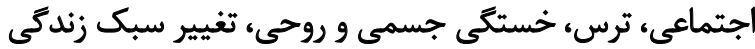

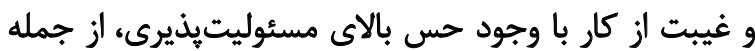

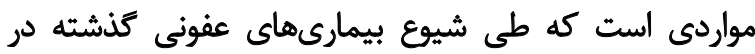

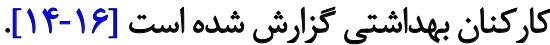

4. Middle East Respiratory Syndrome 
انجام شد. آمار توصيفى براي متغيرهاي كتّى با استفاده از ميانكين

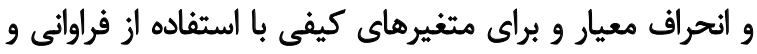

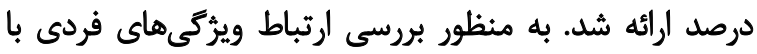

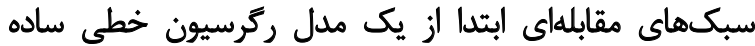

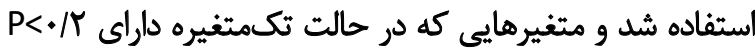

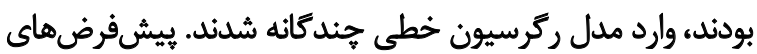

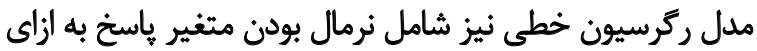

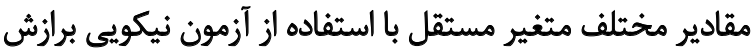

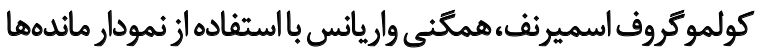

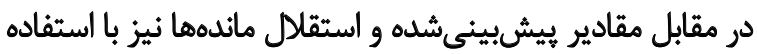

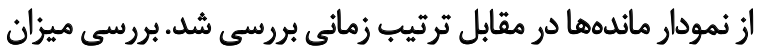

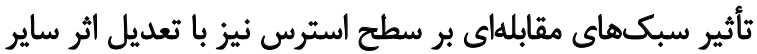

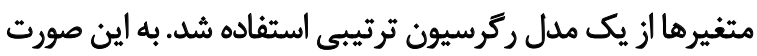

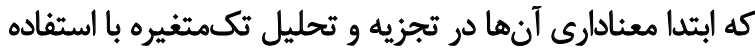

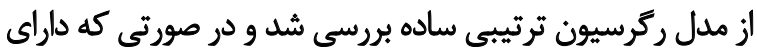

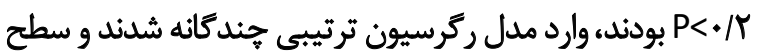

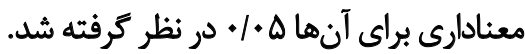

Ldịl

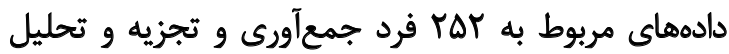

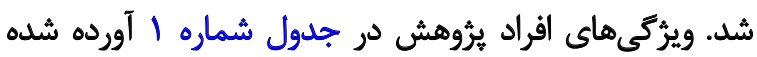

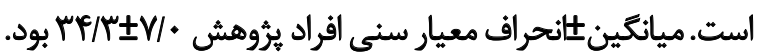

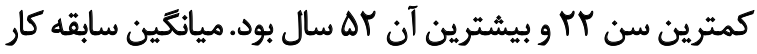

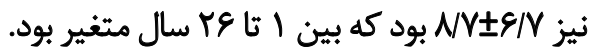

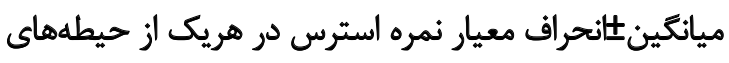

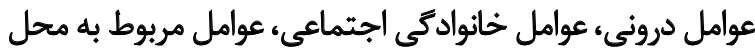

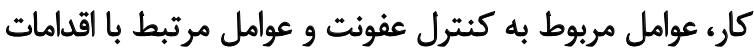
دولتى به ترثيب

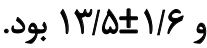

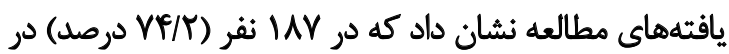

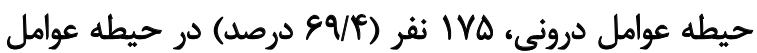

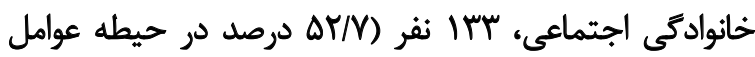

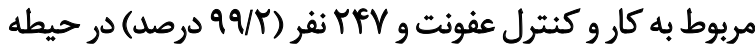
اقدامات دولتى استرس متوسط عار تا شديد داشتند.

ميانكين بانحراف معيار نمره كل استرس نيز

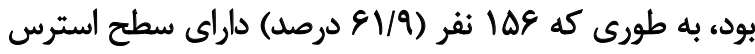

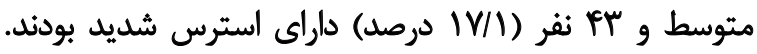

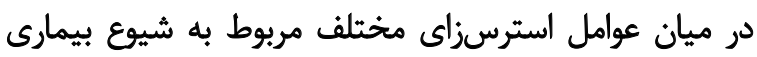

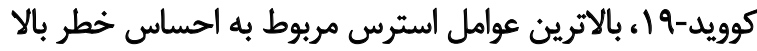
به دليل قرار كرفتن در معرض عفونت كوريد

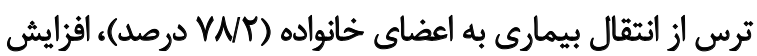

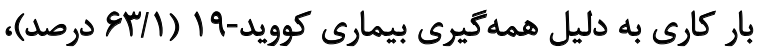
عدم احساس امنيت در كنترل عفونت با وجود استفاده از اقدامات
بعد از تهيه يرسشنامه برخط، لينك آن از طريق ييام كوتاه،

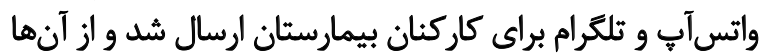

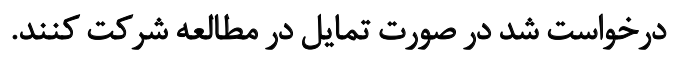

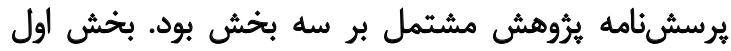

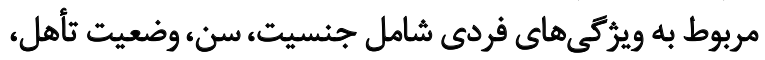
سابقه كار، سطح تحصيلات، شغل، سابقه ابتلا به بئه بيمارى

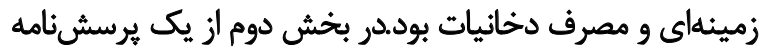

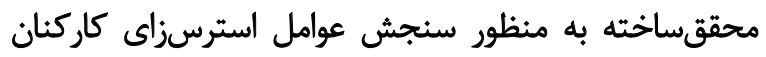

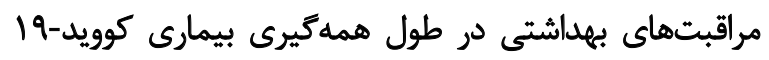

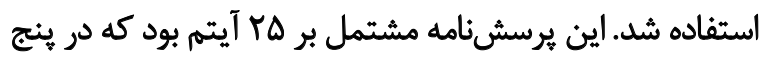

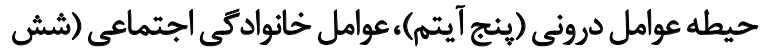

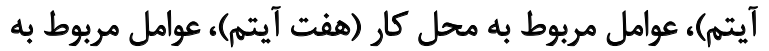

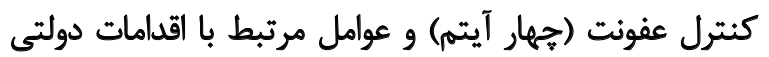

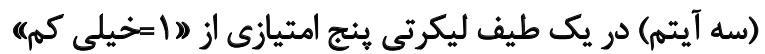

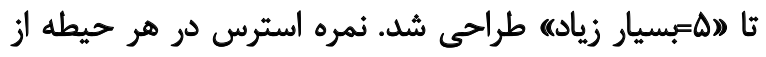

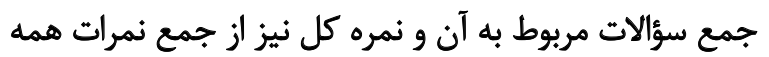

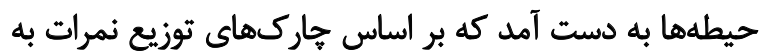

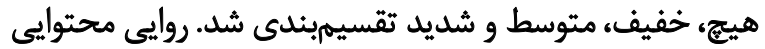

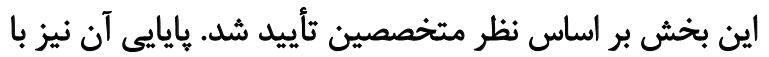

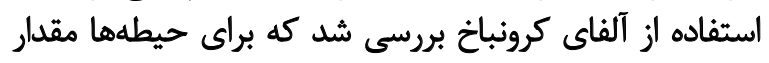

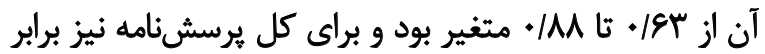

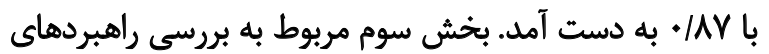

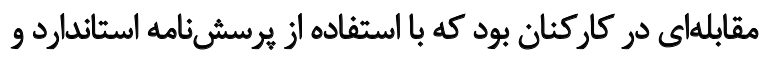
فرم كوتاه راهبردهاى مقابلهاى هار ارزيابى شد.

اين يرسشنامه توسط كارور و همكاران [آن] طراحى شده

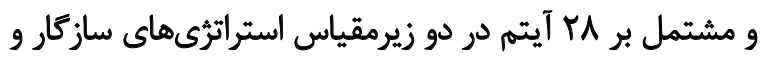

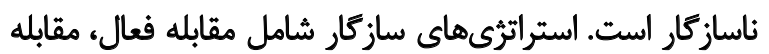

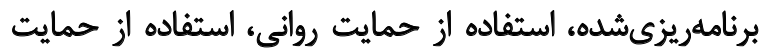

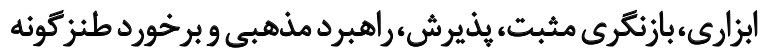

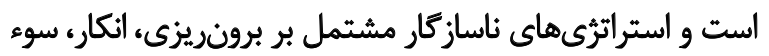

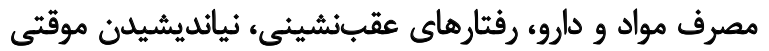

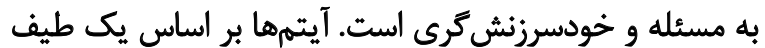

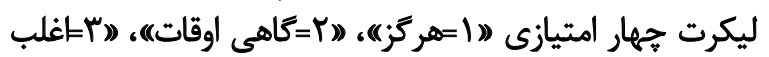

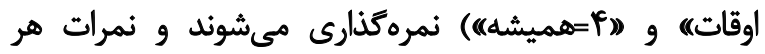

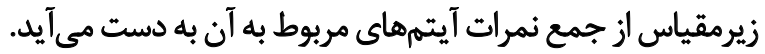

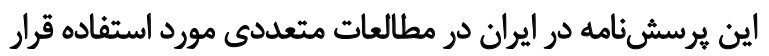

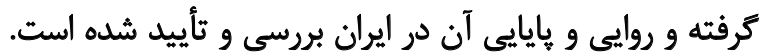

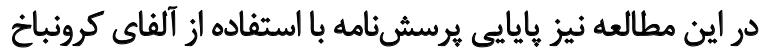

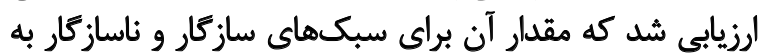

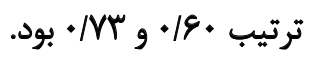

تجزيه و تحليل دادهها با استفاده از نرمافزار SPSS نسخه 19

5. Brief Coping Orientation to Problem Experienced 
جدول ا. ويثَّى هاي شركت كنيدكان مطالعه

\begin{tabular}{|c|c|c|c|c|c|}
\hline \multicolumn{3}{|c|}{ ميزان استرس تعداد (درصد) } & كل & & \multirow{2}{*}{ ويروكى } \\
\hline شديد & هتوسط & هيج / خفيف & تعداد (د,صد) & & \\
\hline$M(N /)$ & Gr $(r q / V)$ & $r \in(r q /)$ & $119(\Delta T / A)$ & ن & \\
\hline $\operatorname{lr}(r V / 9)$ & $q f(\varphi \cdot / M)$ & $M(\Delta \cdot / 9)$ & IIT (PV/Y) & 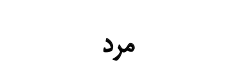 & جُنسيت \\
\hline $\operatorname{lr}(r+/ Y)$ & $m(I f M)$ & $9(\mid \mathrm{V} / \cdot)$ & $P \Delta(I V / A)$ & دييلم و كمتر & \\
\hline$r \Delta(\Delta N Y)$ & $1 \cdots(e+1)$ & $r q(\Delta F / Y)$ & $\operatorname{lof}(F / / 1)$ & كاردانيى و كارشناسى & سطع تحصيلات \\
\hline$\Delta(1 / / 8)$ & $m(M / M)$ & $10(T N M)$ & $\Delta H(T / L)$ & كارشناسي ارثشد و بالاتر & \\
\hline$m(v a / 1)$ & $\operatorname{IrE}(\lambda \cdot / \lambda)$ & $\forall \in(N \in \mid A)$ & $r+\varphi(A) / V)$ & متأهل & 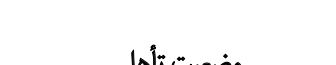 \\
\hline$r \cdot(19 / T)$ & $r \cdot(19 / T)$ & $V(I T / Y)$ & $f \in\left(N^{N}\right)$ & مجرد / مطلقه / بيوه & \\
\hline $\mathbb{1 T}(r \cdot / T)$ & $\Delta r(M F / \cdot)$ & $\mathrm{M}(\mathrm{ME} / \mathrm{H})$ & $A F(M / N)$ & يزشك / يرستار & \\
\hline$T V(E T / A)$ & $V \cdot(19 e / 9)$ & TA (FV/T) & ITY (FNT) & هشاغل بهداشتى وابسته & شغل \\
\hline$r(N / \cdot)$ & $M(T / T)$ & $1 \cdot(\mathrm{NA})$ & $F\left(M N^{*}\right)$ & ادارى & \\
\hline re (Ar/V) & $1 f \cdot(A Q / V)$ & $P V(M V)$ & $M T(M \Delta)$ & خير & \\
\hline$V(1 \% / \pi)$ & $1 \varepsilon(1 \cdot / M)$ & $8(11 / \pi)$ & $r q(11 / \Delta)$ & 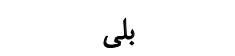 & سابعل ابتَلا به بيمارى زمينهاى \\
\hline$r e(A r / V)$ & $\operatorname{IrV}(A) / P)$ & $P \Delta(A F / q)$ & $r+\Lambda(A Y / \Delta)$ & خير & 1 \\
\hline$V(1 \& / M)$ & rq (WE) & $\wedge(1 \otimes / 1)$ & $P(I V / \Delta)$ & 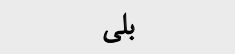 & \\
\hline$r \varepsilon(\varepsilon \cdot / F)$ & $V(f \& / T)$ & $M(M+l e)$ & $118(* 81 \cdot)$ & 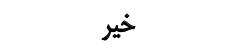 & \\
\hline $\operatorname{lV}(r q / 8)$ & $\operatorname{Af}(\Delta \mathrm{H} / A)$ & $r \Delta(\$ 91 \%)$ & $\operatorname{Irg}(\Delta \mathrm{AH} / \%)$ & 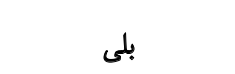 & أنجام فعاليت ورزشيى \\
\hline$m(V q / 1)$ & IFf $(9 T / r)$ & $\operatorname{pr}(A r / \cdot)$ & MTr (WI) & 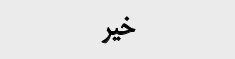 & خلمت در بخش بيماران مبتلا به \\
\hline $9(\%+/ 9)$ & $\operatorname{Ir}(N / N)$ & $q(\mid V / \bullet)$ & $r \cdot(11 / 9)$ & 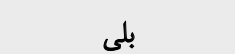 & 19- كويد \\
\hline
\end{tabular}

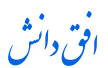

بر اساس آزمون كولموگروف اسميرنف براى ماندهها تأييد شد

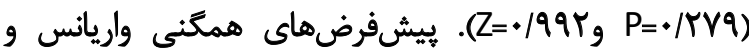
استقلال ماندهها نيز تأييد شد.

نتايج مدل ركرسيون خطى جند إنانه نشان داد كه زنان بيشتر

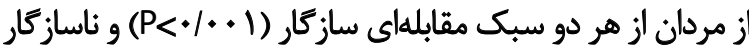
(P=×/F9)

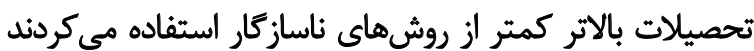

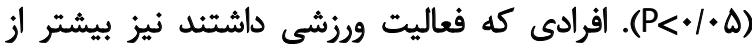

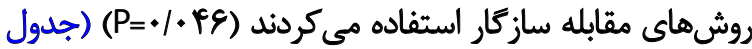

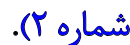

در بررسى ارتباط بين سبكهاى مقابلهاى سازكار و ناسازكار

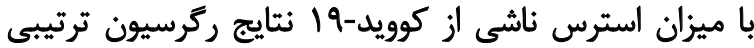

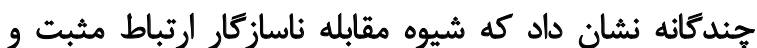

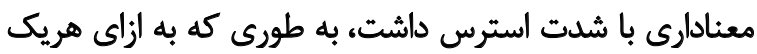

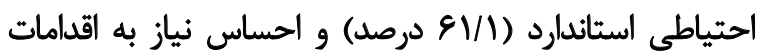

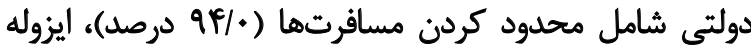

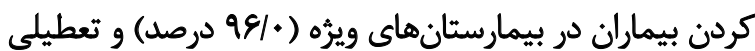
مدارس و مراكز خريد (MN/Q درصد) بودي

نتايج مطالعه نشان داد كه كاركنان بيمارستان در مقابله با

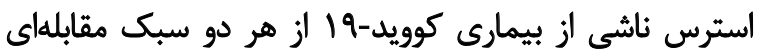

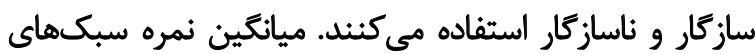

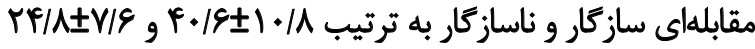

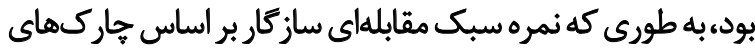

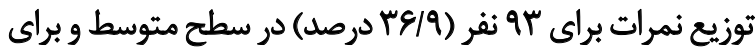

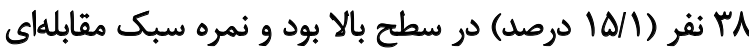

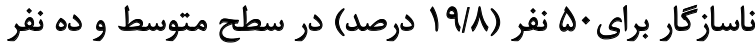

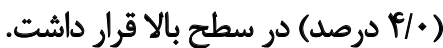

يُشرض نرماليتى متغير ياسخ در مدل ركرسيون خطى 
جدول r. ارتباط بين ويثزى هاى فردى و سبكهاى مقابلهاى سازكار و ناسازگار با استفاده از مدل ركرسيون خطى

\begin{tabular}{|c|c|c|c|c|c|c|}
\hline \multicolumn{3}{|c|}{ مقابله ناساز كار } & \multicolumn{3}{|c|}{ مقابله سازكار } & \multirow{3}{*}{ مدل ركّرسيونى متغيرهاى بيشكو } \\
\hline \multicolumn{2}{|c|}{ جند جنانه } & \multirow{2}{*}{$\begin{array}{c}\text { ساده } \\
\text { B (SE) }\end{array}$} & \multicolumn{2}{|c|}{ 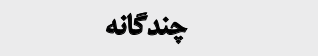 } & \multirow{2}{*}{$\begin{array}{c}\text { oslu } \\
B(S E) \dagger\end{array}$} & \\
\hline $\mathbf{P}$ & $B(S E)$ & & $P$ & $B(S E)$ & & \\
\hline- & $-\infty$ & $-.1 .+(.1 .+1)$ & $\infty$ & $=$ & $.1 \cdot f(\cdot 1 \cdot \Delta)$ & كابقه كار \\
\hline \multirow[t]{2}{*}{$.1 . p q$} &.$/ 9 f(. / M A)$ & $\cdot M^{N}(\cdot / * A) \ddagger$ & $<\cdot 1 .+1$ & $w / M f(\cdot / \& V)$ & $r / 19(. / 8 V)$ & جنسيت (ن) a \\
\hline & & & & & & سطح تحصيلات b \\
\hline.$/ . r i$ & $-1 / R T(\cdot / E T)$ & $-1 / 24(\cdot 18 \pi)$ & . /1we & $r / M(\cdot / A V)$ & $r / M r(\cdot / 91) *$ & كاردائي و كارشناسى \\
\hline$<+1++1$ & $-\operatorname{r/RT}(\cdot / N \Delta)$ & $-r / e P(\cdot N \Delta) * *$ & $.11 \notin 8$ & $r / N F(V / *)$ & r/ag $(V / \cdot q) \dagger$ & كارشناسى ارشد و بالاتر \\
\hline- & -- &.$- / 8 V(\cdot / \& 4)$ & - & - & $\cdot \ln (\cdot 1199)$ & وضعيت تأهل (مثأهل) c \\
\hline- & - & $\cdot 18 \Delta(\cdot M)$ &.$M T A$ &.$- / 4 \Lambda(Y / . r)$ & $-I / M r(1 /+A) \ddagger$ & سابقه بيمارى زمينهاى (بلى) d \\
\hline / /IAF & $\cdot 119(+/ 84)$ & $+/ A r(+/ A r) \neq$ & $\cdot / \Delta \Delta C$ & $-+/ T \&(+/ A Y)$ & $-1 / 49(. / 91) \ddagger$ & استعمال دخانيات (بلى) d \\
\hline- & - & $-.1 .8(. / \times q)$ & .1 .48 & $-1 / \pi /(\cdot \mid \& \Delta)$ & $.119(.189) t$ & انجام فعاليت ورزشى (بلى) d \\
\hline
\end{tabular}

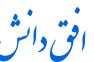

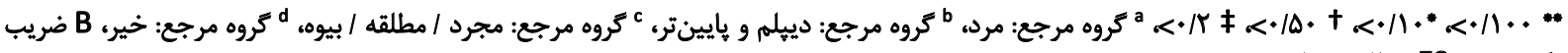
ركرسيونى، ES خطاى معيار. واحد افزايش در نمره مقابله ناساز كار، شانس تجربه سطوح بالاتر

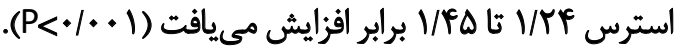

مطالعه حاضر يك مطالعه توصيفي مقطعي بود كه به منظور

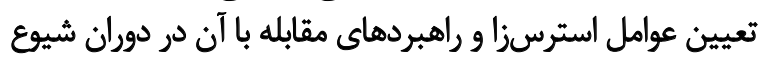

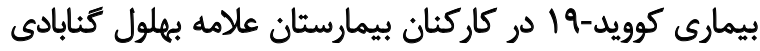

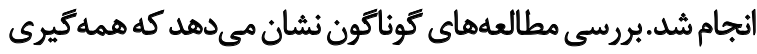

همجينين افرادي كه شانس تجربه سطوح بالاتر استرس در كسانى

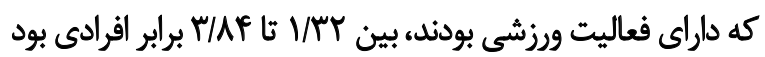

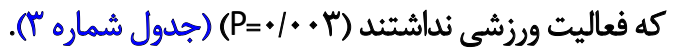

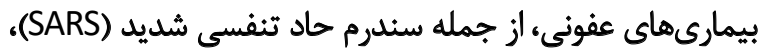

جدول ז. ارتباط بين سبكهاى مقابلهاى سازكار و ناساز مار با سطح استرس با استفاده از مدل ركرسيون ترتيبى

\begin{tabular}{|c|c|c|c|c|}
\hline \multicolumn{2}{|c|}{ ركّر سيون ترتيبي جندكانه } & \multicolumn{2}{|c|}{ رترييون ترتيبي ساده } & \multirow[b]{2}{*}{ مثغير هاى يبشكّو } \\
\hline $\mathbf{P}$ & 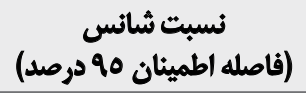 & $\mathbf{P}$ & 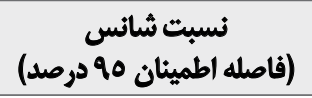 & \\
\hline- & - & . KEV &.$/ 97(\cdot / 97.1 / \cdot 5)$ & 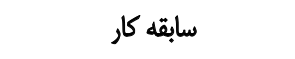 \\
\hline- & - & $+/ \pi 11$ & $1 / \% q\left(+/ M^{*}, r / 94\right)$ & وضعيت تأهل (متأهل) \\
\hline- & - & */eqr & $1 / \pi(\cdot / 8 \cdot \pi / q T)$ & سابقه بيمارى زمينهاى (بلى) d \\
\hline - & - & ./AMr & $V / V(\cdot / \Delta \&, Y / \cdot Y)$ & استعمال دخانيات (بلى) d \\
\hline...$r$ &.$/ F F(. / T \& . . N 8)$ & .1 .1 &.$|\Delta|(\cdot / / N \mid \cdot(A \Delta)$ & انجام فعاليت ورزشى (بلى) d \\
\hline - & - & . MrY &.$/ 99(. / 97.1 / .94)$ & سبكهاى مقابلهاى سازكار \\
\hline$<+1++1$ & $1 / \pi F(1 / T F, V / F \Delta)$ & $<+1++1$ & 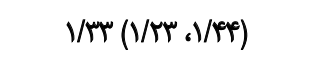 & سبكهاى مقابلهاى ناسازكار \\
\hline
\end{tabular}


مئورزند در مقابله با موقعيتهاي استرسزا احتمالاً داراي افكار

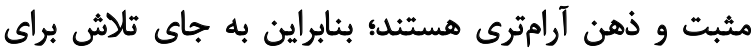

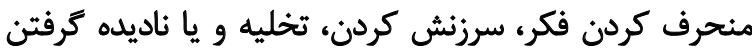

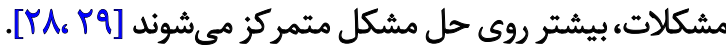
در مطالعه حاضر ، شيوه مقابله ناساز كار ارتباط مثبت و معنادارى

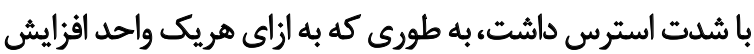

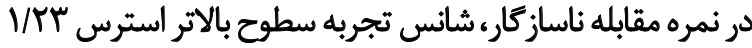

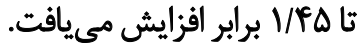

برخى مطالعات ديكر نيز نشان داداند كه مقابلههاي ناساز إنار

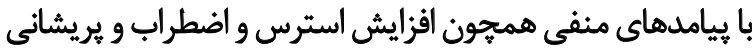

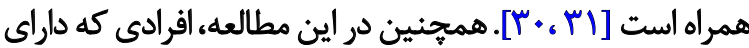

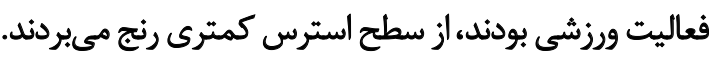
مكانيسم دقيق تأثير ورزش بر كاهش استرس دقيقاً مشخص

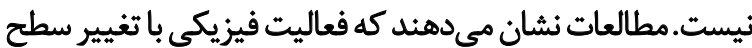

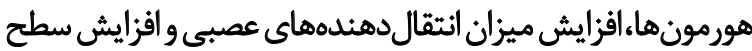

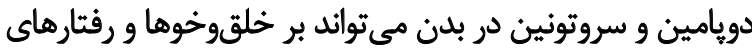

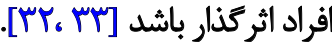

در اين مطالعه، محدوديتهايي نيز وجود داشت. اول اينكه طراحى اين مطالعه به صورت مقطعى بودئ بودئ بنابراين روابط آماري

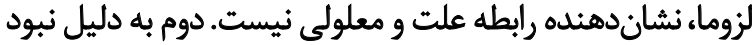

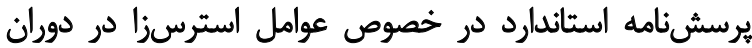

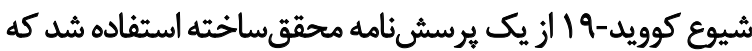

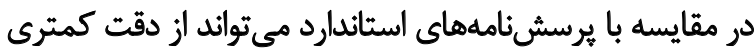

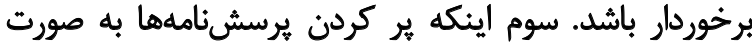

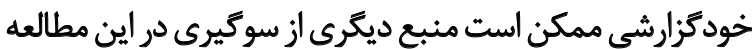

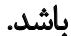

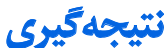

به طور كلى، يافتههاى اين مطالعه نشان مىدهد كه سطح

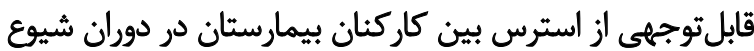

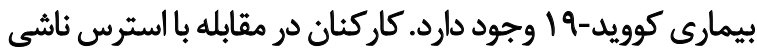

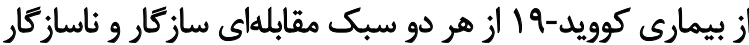

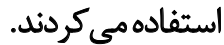

افرادى كه از سبكهاى مقابلهاى ناساز گار استفاده مى كردند،

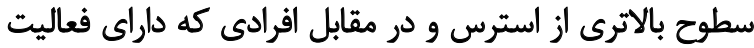

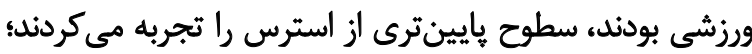

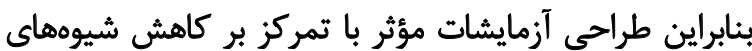

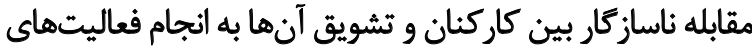

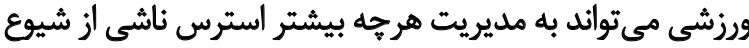
بيمارى كوويد-19 اكمك كند.
سندرم تنفسى خاورميانه (MERS) و آنفولانزاى جديد نوع A سال

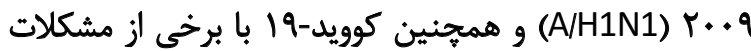
روانى براى كاركنان مراقبتهاى بهداشتى همراه بوده است. مطالعهاى مشابه در طول همه كيرى بيمارى كوويد-19 در دران

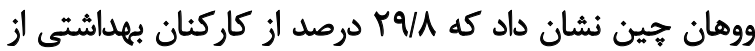

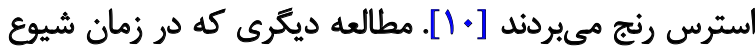

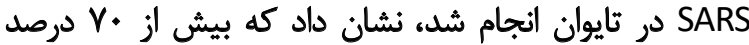

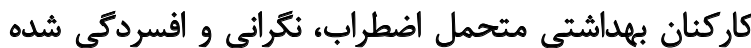

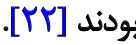

در مطالعهاى در يونان، بيش از • ه درصد كاركنان مراقبتهاى بإي

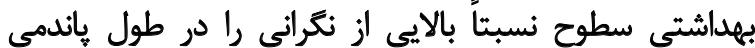

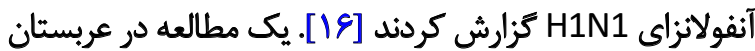

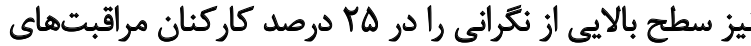

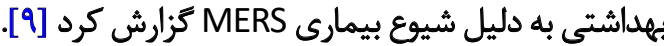

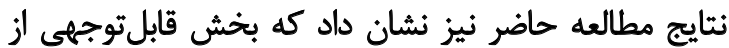

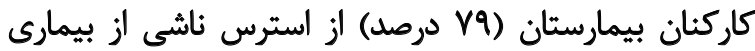

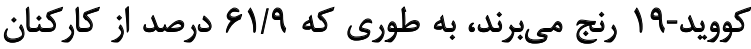

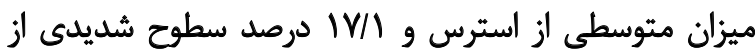

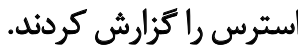

در ميان عوامل استرسزاى مختلف مربوط به شيوع بيمارى

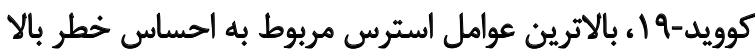
به دليل قرار ترفتن در معرض عفونت كوريد باليد

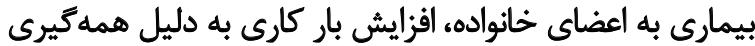

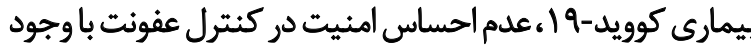

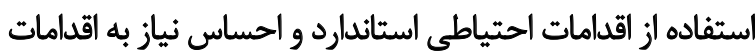

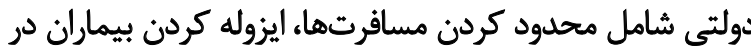

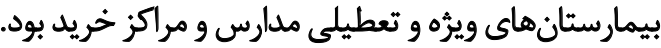
نتايج اين مطالعه نشان داد كه زنان بيشتر از مردان ازئ

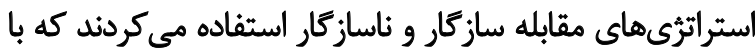

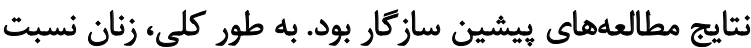

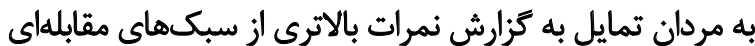

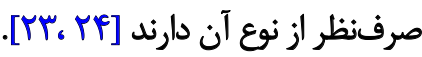

همجئين افراد داراى سطح تحصيلات بالاتر كمتر از روشهاي

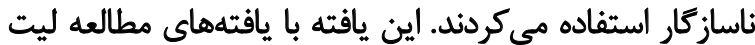

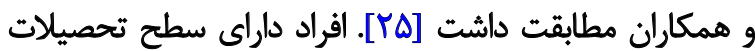

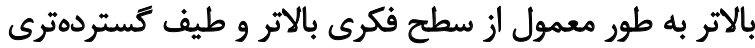

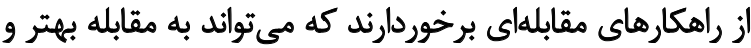

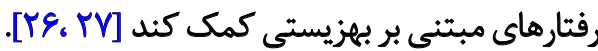
افرادى كه فعاليت ورزشى داشتند نيز بيشتر از روشهاي إنهاي

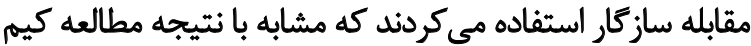

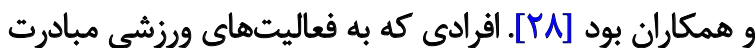


اين مطالعه توسط واحد توسعه تحقيقات بالينى مركز آموزشى،

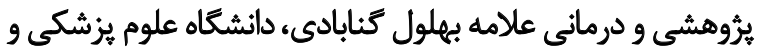

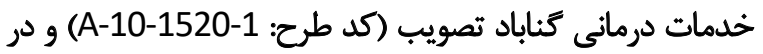

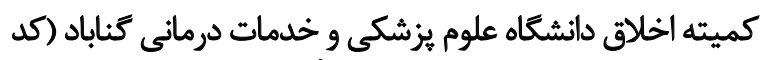
اخلاق: IR.GMU.REC.1398.191) تأييد شد.

در ابتداي يرسشنامه برخط، اطلاعات لازم در مورد مطالعه و

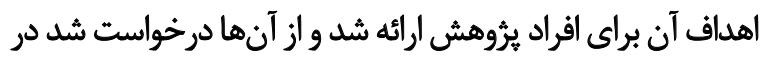

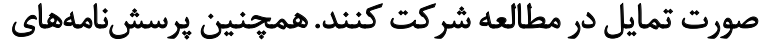
برخط به صورت ناشناس ير شد. مامب مالثي

اين يروهش با حمايت مالى واحد توسعه تحقيقات بالينى مركز

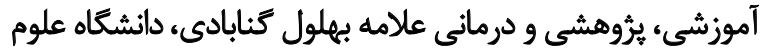
يزشكى و خدمات درمانى كناباد انجام شداند.

مشار كت نويسند مكان

ارائه ايده بُزوهشى: فاطمه محمدزاده؛ طراحى مطالعه: فاطمه

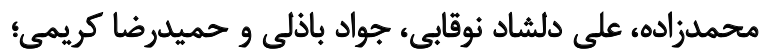

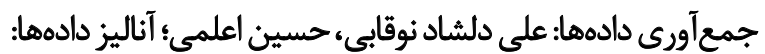

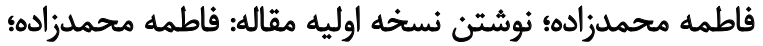

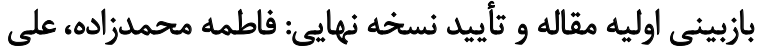

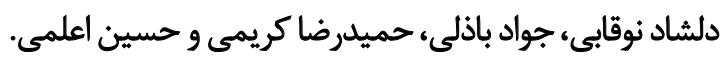

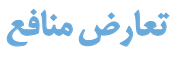

هيجگونه تعارض منافع توسط نويسندكان بيان نشده است.

$$
\text { تشكر وقدردانى }
$$

نويسندكان مقاله از معاونت تحقيقات و فناورى و واحد توسعه

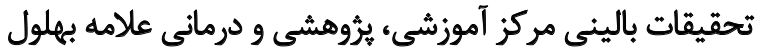

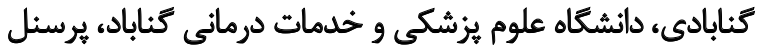

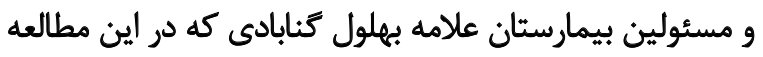
همكارى لازم داشتند، كمال قدردانى و تشكر را دارند. 


\section{References}

[1] World Health Organization. Novel coronavirus (2019-nCoV) situation report -1 [Internet]. 2020 [Updated 2020 January 21]. Available from: https://www.who.int/docs/default-source/coronaviruse/situationreports/20200121-sitrep-1-2019-ncov.pdf?sfvrsn=20a99c10_4

[2] Liu CY, Yang YZ, Zhang XM, Xu X, Dou QL, Zhang WW. The prevalence and influencing factors for anxiety in medical workers fighting COVID-19 in China: A cross-sectional survey. Epidemiology and Infection. 2020; 148:E98. [DOI:10.2139/ssrn.3548781]

[3] World Health Organization. Coronavirus disease (COVID-19) Pandemic [Internet]. 2020 [Updated 2020 June 19]. Available from: https://www.who.int/emergencies/diseases/novel-coronavirus-2019

[4] Kooraki S, Hosseiny M, Myers L, Gholamrezanezhad A. Coronavirus (COVID-19) outbreak: What the department of radiology should know. Journal of the American College of Radiology. 2020; 17(4):44751. [DOI:10.1016/j.jacr.2020.02.008] [PMID] [PMCID]

[5] Mahase E. Coronavirus covid-19 has killed more people than SARS and MERS combined, despite lower case fatality rate. BMJ (Clinical Research ed.). 2020; 368:m641. [DOI:10.1136/bmj.m641] [PMID]

[6] Cai H, Tu B, Ma J, Chen L, Fu L, Jiang Y, et al. Psychological Impact and Coping Strategies of Frontline Medical Staff in Hunan Between January and March 2020 During the Outbreak of Coronavirus Disease 2019 (COVID-19) in Hubei, China. Medical Science Monitor: International Medical Journal of Experimental and Clinical Research. 2020; 26:e924171-1. [DOI:10.12659/MSM.924171]

[7] World Health Organization. Coronavirus disease 2019 (COVID-19) situation report-31 [Internet]. 2020 [Updated 2020 March 27]. https://www.who.int/docs/default-source/coronaviruse/situationreports/20200220-sitrep-31-covid-19.pdf?sfvrsn=dfd11d24_2

[8] Pothiawala S. Psychological impact of the COVID-19 on health care workers in the emergency department. Advanced Journal of Emergency Medicine. 2020; 4(2S):e58. https://fem.tums.ac.ir/index.php/ fem/article/view/397

[9] Abolfotouh MA, AlQarni AA, Al-Ghamdi SM, Salam M, Al-Assiri MH, Balkhy $\mathrm{HH}$. An assessment of the level of concern among hospitalbased health-care workers regarding MERS outbreaks in Saudi Arabia. BMC Infectious Diseases. 2017; 17:4. [DOI:10.1186/s12879-0162096-8] [PMID] [PMCID]

[10] Zhu Z, Xu S, Wang H, Liu Z, Wu J, Li G, et al. COVID-19 in Wuhan: Immediate Psychological Impact on 5062 Health Workers. EClinicalMedicine. 2020; 24:100443. [DOI:10.1101/2020.02.20.20025338]

[11] Bai Y, Lin CC, Lin CY, Chen JY, Chue CM, Chou P. Survey of stress reactions among health care workers involved with the SARS outbreak. Psychiatric Services. 2004; 55(9):1055-7. [DOI:10.1176/appi. ps.55.9.1055] [PMID]

[12] Lee SM, Kang WS, Cho AR, Kim T, Park JK. Psychological impact of the 2015 MERS outbreak on hospital workers and quarantined hemodialysis patients. Comprehensive Ppsychiatry. 2018; 87:123-7. [DOI:10.1016/j.comppsych.2018.10.003] [PMID] [PMCID]

[13] Goulia P, Mantas C, Dimitroula D, Mantis D, Hyphantis T. General hospital staff worries, perceived sufficiency of information and associated psychological distress during the A/H1N1 influenza pandemic. BMC Infectious Diseases. 2010; 10:322. [DOI:10.1186/1471-233410-322] [PMID] [PMCID]

[14] Maunder RG, Lancee WJ, Rourke S, Hunter JJ, Goldbloom D, Balderson $\mathrm{K}$, et al. Factors associated with the psychological impact of severe acute respiratory syndrome on nurses and other hospital workers in Toronto. Psychosomatic Medicine. 2004; 66(6):938-42 [DOI:10.1097/01.psy.0000145673.84698.18] [PMID]

[15] Nickell LA, Crighton EJ, Tracy CS, Al-Enazy H, Bolaji Y, Hanjrah S, et al. Psychosocial effects of SARS on hospital staff: Survey of a large tertiary care institution. CMAJ: Canadian Medical Association Journal = Journal de I'Association Medicale Canadienne. 2004; 170(5):793-8. [DOI:10.1503/cmaj.1031077] [PMID] [PMCID]

[16] Goulia P, Mantas C, Dimitroula D, Mantis D, Hyphantis T. General hospital staff worries, perceived sufficiency of information and associated psychological distress during the $\mathrm{A} / \mathrm{H} 1 \mathrm{~N} 1$ influenza pandemic. $\mathrm{BMC}$ Infectious Diseases. 2010; 10:322. [DOI:10.1186/1471-2334-10-322] [PMID] [PMCID]

[17] Smith MM, Saklofske DH, Keefer KV, Tremblay PF. Coping strategies and psychological outcomes: The moderating effects of personal resiliency. The Journal of Psychology. 2016; 150(3):318-32. [DOI:10.1080/00 223980.2015.1036828] [PMID]

[18] Lazarus RS, Folkman S. Stress, appraisal, and coping. New York: Springer Publishing Company; 1984. https://books.google.com/books/about/ Stress_Appraisal_and_Coping.html?id=FFBqAAAAMAAJ\&source $=\mathrm{kp}$ book_description

[19] Folkman S, Moskowitz JT. Coping: Pitfalls and promise. Annual Review of Psychology. 2004; 55:745-74. [DOI:10.1146/annurev. psych.55.090902.141456] [PMID]

[20] Grech LB, Kiropoulos LA, Kirby KM, Butler E, Paine M, Hester R. Target coping strategies for interventions aimed at maximizing psychosocial adjustment in people with multiple sclerosis. International Journal of MS care. 2018; 20(3):109-19. [DOI:10.7224/1537-2073.2016-008] [PMID] [PMCID]

[21] Carver CS. You want to measure coping but your protocol's too long: Consider the brief COPE. International Journal of Behavioral Medicine. 1997; 4:92. [DOI:10.1207/s15327558ijbm0401_6] [PMID]

[22] Chong MY, Wang WC, Hsieh WC, Lee CY, Chiu NM, Yeh WC, et al. Psychological impact of severe acute respiratory syndrome on health workers in a tertiary hospital. The British Journal of Psychiatry. 2004; 185(2):127-33. [DOI:10.1192/bjp.185.2.127] [PMID]

[23] Kaiseler M, Polman RC, Nicholls AR. Gender differences in appraisal and coping: An examination of the situational and dispositional hypothesis. International Journal of Sport Psychology. 2012; 43:1-14. https:// eprints.qut.edu.au/106339/

[24] Tamres LK, Janicki D, Helgeson VS. Sex differences in coping behavior: A meta-analytic review and an examination of relative coping. Personality and Social Psychology Review. 2002; 6(1):2-30. [DOI:10.1207/ S15327957PSPR0601_1]

[25] Leite FMC, Amorim MHC, Castro DSC, Vasconcellos EG, Primo CC Coping strategies and the relationship with sociodemographic conditions of women with breast cancer. Acta Paulista de Enfermagem. 2012; 25(2):211-7. [DOI:10.1590/S0103-21002012000200009]

[26] Nowak Z, Wańkowicz Z, Laudanski K. Denial defense mechanism in dialyzed patients. Medical Science Monitor: International Medical Journal of Experimental and Clinical Research. 2015; 21:1798-805. [DOI:10.12659/MSM.893331] [PMID] [PMCID]

[27] Baharom N, Hassan MR, Ali N, Shah SA. Improvement of quality of life following 6 months of methadone maintenance therapy in Malaysia. Substance Abuse Treatment, Prevention, and Policy. 2012; 7:32. [DOI:10.1186/1747-597X-7-32] [PMID] [PMCID] 
[28] Kim JH, McKenzie LA. The impacts of physical exercise on stress coping and well-being in university students in the context of leisure. Health. 2014; 6:2570-80. [DOI:10.4236/health.2014.619296]

[29] Azizi M. Effects of doing physical exercises on stress-coping strategies and the intensity of the stress experienced by university students in Zabol, Southeastern Iran. Procedia-Social and Behavioral Sciences. 2011; 30:372-5. [DOI:10.1016/j.sbspro.2011.10.073]

[30] Penley JA, Tomaka J, Wiebe JS. The association of coping to physical and psychological health outcomes: A meta-analytic review. Journal of Behavioral Medicine. 2002; 25(6):551-603. [DOI:10.1023/A:1020641400589] [PMID]

[31] Maunder RG, Lancee WJ, Balderson KE, Bennett JP, Borgundvaag $B$, Evans S, et al. Long-term psychological and occupational effects of providing hospital healthcare during SARS outbreak. Emerging Infectious Diseases. 2006; 12(12):1924-132. [DOI:10.3201/eid1212.060584] [PMID] [PMCID]

[32] Esch T, Stefano GB. Endogenous reward mechanisms and their importance in stress reduction, exercise and the brain. Archives of Medical science. 2010; 6(3):447-55. [DOI:10.5114/aoms.2010.14269] [PMID] [PMCID]

[33] Greenwood BN, Fleshner M. Exercise, stress resistance, and central serotonergic systems. Exercise and Sport Sciences Reviews. 2011; 39(3):140-9. [DOI:10.1097/JES.0b013e31821f7e45] [PMID] [PMCID] 